The result was rather disappointing. The alcoholic solutions remained clear for many hours. From the aqueous solutions crystals of both bromide and iodide were obtained, but of such small size that it was difficult to make out their forms. Those of the iodide were slightly larger and less deliquescent and under the microscope showed rhombic needles and prisms. somewhat rouncted, so as to resemble some forms of uric acid.

But they were so difficult to separate from the solution without adhering liquid. that weighing could only be approximate. and most likely would include some liquid as well as the dry substance.

'The bronicle, on titration, yielded 62.3 per cent. of calcinm bromide, which would approximate the formula $\mathrm{CaBr}_{2}+6 \mathrm{H}_{2} \mathrm{O}$. which requires 64.92 per cent of calcium bromide, and 35.08 per cent. of water.

The iodicle yielded 69.9 per cent. of calcium iodide; the formula CaI $+6 \mathrm{H}_{2} \mathrm{O}$ would demand 7.3. I per cent.

In both salts the adhering liquid would render the result somewhat uncertain, and the yield of dry substance too low.

The evidence thus far is certainly not sufficient to draw definite conclusions, but $I$ believe that the existence of hyclrates of the formula $\mathrm{CaBr}+6 \mathrm{H}_{2} \mathrm{O}$ and $\mathrm{CaBr}_{2}+{ }_{3} \mathrm{H}_{2} \mathrm{O}$, as well as of the corresponding hydrates of calcium iodide, is very probable.

July $\hookrightarrow$, : $\backslash 94$

\title{
A STUDY OF THE CHEMICAL BEHAVIOR OF ARSENOPYRITE.
}

By Thomas Montrumery laghtfoot.

Receives June 23,2894

THE variation in the weathering of pyrite, marcasite, and pyrrhotite, so often to be observed in nature, has already furnished material for several papers on the subject. The consideration of these differences in behavior leads to the question involving the chemical difference between these and allied mineral species. The effect of the electric current on these naturally occurring sulphides and sulpharsenides has already been investigated in this laboratory, but, so far as I am aware, no series of experiments with various oxidants has been recorded. Investigations as to the effect of potassium permanganate on 
pyrite, ${ }^{1}$ marcasite, ${ }^{\prime}$ and pyrrhotite have been in progress during the period occupied by the experiments described in this paper. At the suggestion, therefore, of Prof. Edgar F. Smith, I undertook the study of arsenopyrite in several directions with the results that follow.

The material used in this investigation was obtained from the dump of an abandoned mine in Maine and was purchased from a dealer. The mitieral was associated with quartz, with apparutly no other impurity so far as the mass was concerned. To separate this quartz the mass was crushed until it passed through a twenty-four mesh screen; it was then subjected to a rising stream of water in a $U$ tube which floated off the quartz and mixed grains. The material remaining in the tube was found to be entirely free from quartz. The pure material was then washed with distilled water, spread on a filter paper, and dried at a gentle heat. A magnet was used to remove any particles of iron that might have entered the material from the crusher. This purified arsenopyrite was then preserved in a glass-stoppered bottle, and portions of it ground from time to time as required in an agate mortar. An estimation of the total sulphur contained in this arsenopyrite gave as the average of three determinations 19.77 per cent., almost the theoretical for the ratio of $\mathrm{FeS}_{2}$ to $\mathrm{FeAs}_{2}$ as I : I.

Action of Potassizm Permanganate at the Ordinary Temperature.-The first series of experiments consisted in determining the effect of potassium permanganate solutions of varying strengths on the mineral, the oxidant being allowed to act for varying periods of time and at $100^{\circ}$ as well as at the ordinary temperature $\left(21^{\circ}-22^{\circ}\right)$. The method of procedure at the ordinary temperature was the same in each case, and was as follows: Two-tenths of a gram of the finely ground mineral were introduced into a glass-stoppered bottle and fifty $\mathrm{cc}$. of the permanganate solution added. The bottle and its contents were then shaken at frequent intervals to prevent the caking of the mineral against the walls of the vessel and to expose fresh surfaces to the action of the permanganate. Four strengths of solution were employed, $\tau_{1}^{\frac{1}{\delta} \sigma}$ normal, one per cent., three per cent., and five

I See "A Comparative Study of the Chemical Behavior of Pytite aud Marcasite." by A. P. Brown. Proc. Amer. Philos. Soc., 1891 . 
per cent., and each was allowed to act for periods of one, two, three, four, and five hours. Duplicate trials were made in each case. After the solution had been in contact with the mineral for the specifin a time the contents of the bottle were thrown on a filter, $t$ e residut was washed on the filter and rejected, and the filtrate - as acidifi d with hydrochloric acid and the sulphur oxidized, and determined as barium sulphate. In this determination trouble was experienced in obtaining complete precipitation of the sulphuric acid, even after long digestion and standing, and this may account in part for the great irregularities shown in the results of these oxidations. It should be noted that the four-hour experiments (which show notable irregularities) were performed after the completion of the rest of the series, but presumably under the same conditions.

The results of this series of oxidations are tabulated below. It will be noticed that the two results given in each case sometimes correspond closely with each other and at other times one is more than double the other. There is no reason why these results should vary in this way so far as external conditions are concerned as these duplicates were in each case made at the same time and under the same conditions. The average of the two in a number of cases would seem to be nearer the expected result. Omitting consideration of the four-hour trials, reference to which has already been made, it is seen that in each,case the oxidation is practically completed at the end of the first hour, and is comparatively slight after all. The mineral is not nearly so readily affected by this oxidant as the simple iron sulphides.

(1) TABle ShowiNg THE AMovir of Sulphur Oxidized in ARsenoPYRITE BY POTASSIUM PERMANGANATE AT THY

ORDINARY TEMPERATURE.

\begin{tabular}{|c|c|c|c|c|c|c|c|c|c|c|}
\hline \multirow[b]{2}{*}{$\begin{array}{c}\text { Strength } \\
\text { of per- } \\
\text { manganate } \\
\text { solution. }\end{array}$} & \multicolumn{2}{|c|}{$\begin{array}{l}\text { One hour. } \\
\text { Sul. } \\
\text { phut }\end{array}$} & \multicolumn{2}{|c|}{$\begin{array}{l}\text { Two hours. } \\
\text { sul- } \\
\text { phur }\end{array}$} & \multicolumn{2}{|c|}{$\begin{array}{l}\text { Three hours. } \\
\text { sul- } \\
\text { phur }\end{array}$} & \multicolumn{2}{|c|}{$\begin{array}{l}\text { Four hours. } \\
\text { Sul. } \\
\text { phur }\end{array}$} & \multicolumn{2}{|c|}{$\begin{array}{l}\text { Five hours. } \\
\text { Sul- } \\
\text { phur }\end{array}$} \\
\hline & $\begin{array}{l}\text { phur } \\
\text { oxid- } \\
\text { ized. } \\
\text { Per } \\
\text { cent. }\end{array}$ & $\begin{array}{l}\text { Aver- } \\
\text { age. } \\
\text { Per } \\
\text { cent. }\end{array}$ & $\begin{array}{l}\text { phur } \\
\text { oxidd } \\
\text { ized. } \\
\text { Per } \\
\text { ceut. }\end{array}$ & $\begin{array}{l}\text { Aver- } \\
\text { age. } \\
\text { Per } \\
\text { ceut. }\end{array}$ & $\begin{array}{l}\text { phur } \\
\text { oxid. } \\
\text { ized. } \\
\text { Per } \\
\text { cent. }\end{array}$ & $\begin{array}{l}\text { Aver- } \\
\text { age. } \\
\text { Per } \\
\text { cent. }\end{array}$ & $\begin{array}{l}\text { phur } \\
\text { oxid. } \\
\text { ized. } \\
\text { Pet } \\
\text { cent. }\end{array}$ & $\begin{array}{l}\text { Aver- } \\
\text { age. } \\
\text { Pet } \\
\text { cent. }\end{array}$ & $\begin{array}{l}\text { phur } \\
\text { oxid. } \\
\text { ized. } \\
\text { Per } \\
\text { cent. }\end{array}$ & $\begin{array}{l}\text { Aver- } \\
\text { age. } \\
\text { Per } \\
\text { cent. }\end{array}$ \\
\hline & 0.34 & & 0.34 & & 0.33 & & 0.53 & & 0.52 & \\
\hline ort & 0.33 & 0.33 & 0.34 & 0.34 & 0.49 & 0.41 & $0.5 \mathrm{I}$ & 0.52 & 0.27 & 0.3 \\
\hline & 0.25 & & $0.3^{2}$ & & 0.38 & & 0.73 & & 0.25 & \\
\hline & $0.5^{8}$ & 0.42 & 0.24 & .20 & 0.40 & 0.39 & 0.75 & 0.74 & 0.46 & 5 \\
\hline & $0.6 \mathrm{I}$ & 0.56 & 0.43 & & 0.40 & & 1.20 & I, 30 & 0.55 & \\
\hline & 0.52 & $0.5^{\circ}$ & 0 & 30 & 0.3 & .39 & 1.40 & 1.30 & 0.44 & $0.5^{\circ}$ \\
\hline & $\begin{array}{l}0.41 \\
0.16\end{array}$ & 0.29 & $\begin{array}{l}0.27 \\
0.75\end{array}$ & $.5 \mathrm{I}$ & 0.34 & 0.52 & 0.25 & 0.44 & 0.59 & 0.48 \\
\hline & 0.10 & & .75 & & 0.09 & & 0.63 & & 0.33 & \\
\hline
\end{tabular}


Action of Potassium Permanganate at $100^{\circ}$.- In conducting experiments at $100^{\circ}$ the bottles containing the mineral and permanganate solution were suspended in boiling water, which covered about one-half of the bottle, and the stoppers introduced after the contents of the bottle had reached the temperature of the water. The other details of these experiments were the same as for those conducted at the ordinary temperature. The action in this case was considerably more energetic, and the results obtained were much more concordant. The best results in this case were with the $\frac{1}{10 \sigma}$ normal solution which are remarkably close in duplicate and the averages show a regular rise in the amount of sulphur oxidized in proportion to the time of oxidation. The one per cent. solution gave discordant results, but curiously the averages show a fairly regular rate of oxidation. The three and five per cent. solutions give concordant results in duplicate and show on the other hand an approach to the character of oxidation shown at the ordinary temperature, but several times greater in degree. The oxidation for each of the three and five per cent. solutions seems to be nearly complete at the end of the first hour, the rate of oxidation thereafter being very slow.

The results of this series of experiments are given it1 the following table, along with their averages:

(2) TABLE Showing The Amount of Sulphlir Oxidized IN ARseñoPYRITE BY POTASSIUM PERManganate at $100^{\circ}$

\begin{tabular}{|c|c|c|c|c|c|c|c|c|c|c|}
\hline $\begin{array}{l}\text { Str } \\
\text { of }\end{array}$ & $\begin{array}{c}\text { One } \\
\text { Sul- } \\
\text { phur } \\
\text { oxid- } \\
\text { ized. } \\
\text { Per } \\
\text { cent. }\end{array}$ & $\begin{array}{l}\mathrm{Av} \\
\mathrm{ag} \\
\mathrm{Pe} \\
\mathrm{cen}\end{array}$ & $\begin{array}{c}\text { Two } \\
\text { Sul- } \\
\text { phur } \\
\text { oxid- } \\
\text { ized. } \\
\text { Per } \\
\text { cent. }\end{array}$ & $\begin{array}{c}\text { Av } \\
\text { a } \\
\text { Pe }\end{array}$ & $\begin{array}{l}\text { Sul- } \\
\text { phur } \\
\text { oxid- } \\
\text { ized. } \\
\text { Per } \\
\text { cent. }\end{array}$ & $\begin{array}{c}A v \\
\mathrm{a} \\
\mathrm{P} \\
\mathrm{ce}\end{array}$ & $\begin{array}{l}\text { Sul- } \\
\text { phur } \\
\text { oxid- } \\
\text { ized. } \\
\text { Per } \\
\text { cent. }\end{array}$ & $\begin{array}{r}A_{1} \\
\vec{P} \\
\mathrm{c}\end{array}$ & $\begin{array}{l}\text { Ful- } \\
\text { phur } \\
\text { oxid. } \\
\text { ized. } \\
\text { Per } \\
\text { cent. }\end{array}$ & $\begin{array}{l}A \\
B\end{array}$ \\
\hline & 0.60 & & 0.82 & & 1.05 & & 1.09 & & I.28 & \\
\hline & 0.57 & 0.59 & $0.7 \mathrm{I}$ & 0.77 & 1.06 & 1.05 & I. 30 & I. 1 & $1.3 \mathrm{I}$ & \\
\hline Der & $\begin{array}{l}1.06 \\
0.29\end{array}$ & 0.67 & $\begin{array}{l}\text { I. } 44 \\
0.83\end{array}$ & I.I3 & $\begin{array}{l}2.27 \\
0.24\end{array}$ & 5 & $\begin{array}{l}\text { I.25 } \\
\text { I. } 28\end{array}$ & .27 & $\begin{array}{l}1.46 \\
0.25\end{array}$ & \\
\hline & $\begin{array}{l}1.45 \\
1.18\end{array}$ & 1.31 & $\begin{array}{l}1.36 \\
1.16\end{array}$ & .26 & $\begin{array}{l}1.6 \mathrm{I} \\
\mathrm{I} .45\end{array}$ & I.53 & $\begin{array}{l}1.56 \\
\text { I. } 59\end{array}$ & 1.57 & $\begin{array}{l}1.24 \\
1.95\end{array}$ & \\
\hline & $\begin{array}{l}1.12 \\
1.68\end{array}$ & I.4 & $\begin{array}{l}\mathrm{I} .25 \\
\mathrm{I} .40\end{array}$ & I.33 & $\begin{array}{l}\mathrm{I}: 36 \\
\mathrm{I} .46\end{array}$ & $1.4^{1}$ & $\begin{array}{l}\text { I. } 74 \\
\text { I. } 80\end{array}$ & 1.77 & $\begin{array}{l}1.70 \\
1.75\end{array}$ & \\
\hline
\end{tabular}

The foregoing results will be more significant if compared with the results of similar experiments made with related minerals. As already noted, experiments on the chemical behavior of pyrite 
and marcasite have been conducted in this laboratory recently, and from the arerage results of the action of potassium permanganate on the above two minerals I have been enabled to compile a comparative table in which they are compared with my results on arsenopyrite. In order to compare the action of the permanganate on the sulphur of these thee minerals on equal terms, I have calculated from lirown's tabulated results of average amounts oxidized the percentage of the contained sulphur oxidized, and doing the same for ny arerages on arsenopyrite hare combined these calculated percentages in a table in which the action of varying strengths of solution for varying times on the three minerals can be seen at a glance.

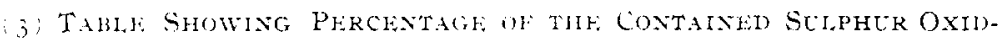
TZFE 135 POMASSITM PERMANGANATE IN AKSFNOPYRITH

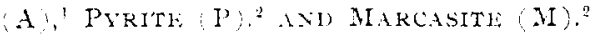

\begin{tabular}{|c|c|c|c|c|c|c|c|}
\hline & Ont & 'Ihrtes & five & & Ot1E & Three & Five \\
\hline ath & $p \in$ & jut & per & 100 & per & pet & pet \\
\hline $\begin{array}{l}\text { homillal. } \\
22^{\circ} \text {. }\end{array}$ & $\begin{array}{c}\text { cent } \\
22^{\circ} .\end{array}$ & $\begin{array}{c}\text { cent. } \\
22^{-}\end{array}$ & $\begin{array}{c}c+11 t \\
22\end{array}$ & $\begin{array}{c}\text { nornal. } \\
\text { Jol? }\end{array}$ & $\begin{array}{l}\text { cent, } \\
\text { Iso". }\end{array}$ & $\begin{array}{l}\text { cent. } \\
\text { soc. }\end{array}$ & $\begin{array}{l}\text { cellt. } \\
\text { roo. }\end{array}$ \\
\hline
\end{tabular}

$\left\{\begin{array}{lllllllll}A & 1.69 & 2.12 & 2.75 & 1.45 & 2.98 & 3.44 & 6.66 & 7.11\end{array}\right.$

One hour... $\begin{array}{lllllllll}P & 1.46 & 3.20 & 4.78 & 5.19 & 7.59 & \text { I1.3I } & \text { II.74 } & 14.91\end{array}$

$\begin{array}{lllllllll}\mathrm{M} & 2.01 & 2.29 & 5.25 & 4.33 & 5.94 & 12.06 & 12.13 & 15.52\end{array}$

Two hours. $\left\{\begin{array}{rrrrrrrrr}A & 1.73 & 1.4 \mathrm{I} & 1.83 & 2.6 \mathrm{I} & 3.89 & 5.74 & 6.14 & 6.74 \\ \mathrm{P} & 2.19 & 2.68 & 4.26 & 5.79 & 8.85 & 13.09 & 12.81 & 1.4 .10\end{array}\right.$

Two hours.. $\left\{\begin{array}{rrrrrrrrr}1 & 2.19 & 2.68 & 4.26 & 5.79 & 8.85 & 13.09 & 12.81 & 14.10 \\ \text { MI } & 3.48 & 2.27 & 4.18 & 6.39 & 7.20 & 11.12 & 14.94 & 15.5^{2}\end{array}\right.$

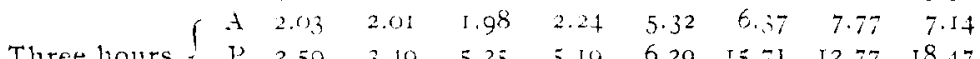

Three hours. $\begin{array}{lllllllll}\mathrm{P} & 2.59 & 3.49 & 5.25 & 5.19 & 6.29 & 15.71 & \mathrm{I} 2.77 & 18.47\end{array}$

$\begin{array}{rrrrrrrrr}\text { II } & 3.82 & 3.86 & 5.38 & 6.18 & 7.04 & 16.05 & 17.66 & 24.88 \\ \text { A } & 2.66 & 3.74 & 6.58 & 2.24 & 6.04 & 6.43 & 8.00 & 8.88\end{array}$

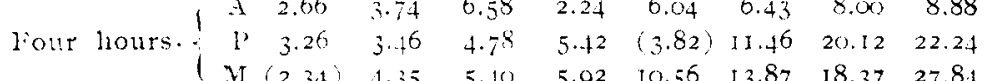

$\begin{array}{lllllllrr}\text { AI } & (2.34) & 4.35 & 5.40 & 5.92 & 10.56 & 13.87 & 18.37 & 27.84 \\ \mathrm{~A} & 2.0 \mathrm{I} & 1.81 & 2.52 & 2.36 & 6.6 \mathrm{I} & 4.33 & 8.08 & 8.76\end{array}$

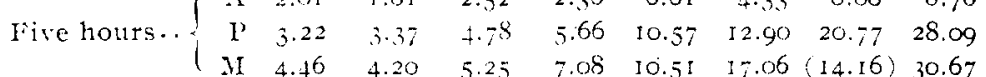

From the above table a plat has been macle to show the rates of oxidation of sulphur in arsenopyrite by different strengths of potassium permanganate solutions acting for different times, the results obtained by each strength of solution being combined into a continuous curve (Plate I). The points already mentioned above as to the action of different strengths of solution

1 Calculated from averages as given in Tables (1) and (2).

2 Calculated from average results as given by Brown in "A Comparative study of the Chemical Behavior of Pyrite and Marcasite." Proc. Amer. Philos. Sor, 1894. 
are here graphically shown. A large value has been given the vertical component (percentage oxidized) in order to separate the curves more fully.

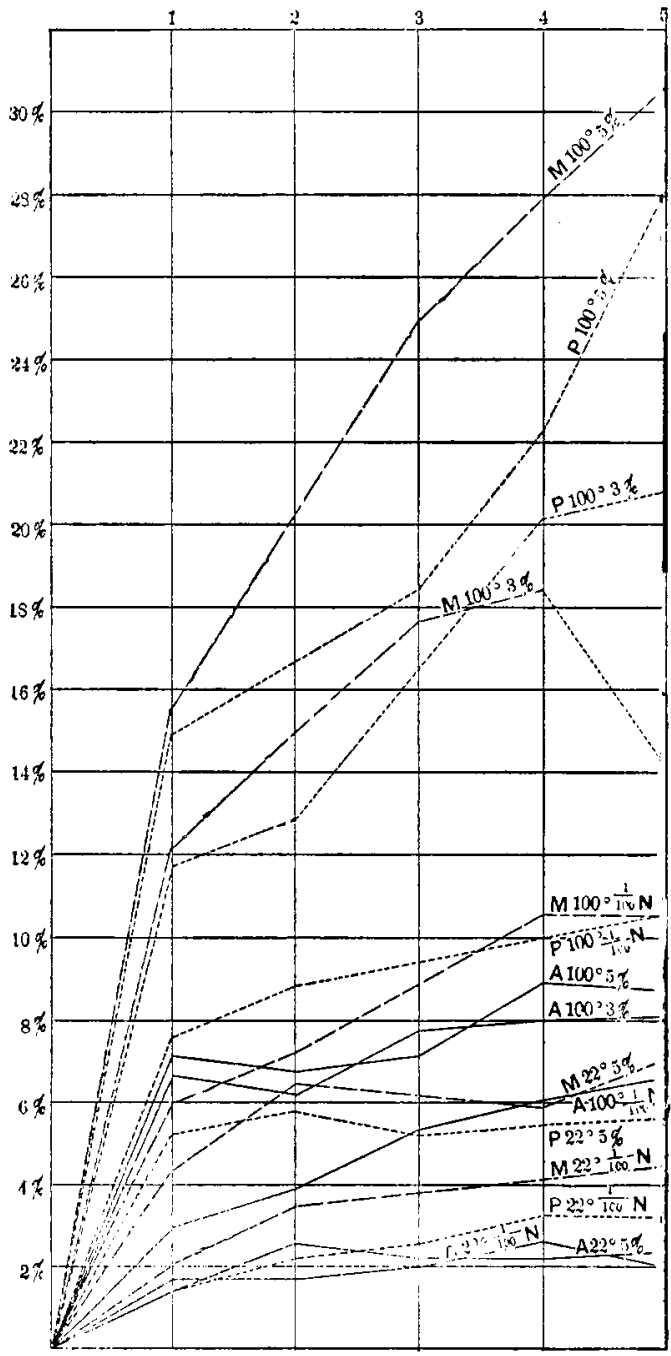

PLATE I.

A comparative plat is also given (Plate II) of selected results from table (3) in which only those curves for arsenopyrite are 
630 THOMAS MONTGOMERY LIGHTFOOT. A STUDY OF

selected which present a reasonable degree of regularity. They are not, however, necessarily the best in the pyrite-marcasite series.

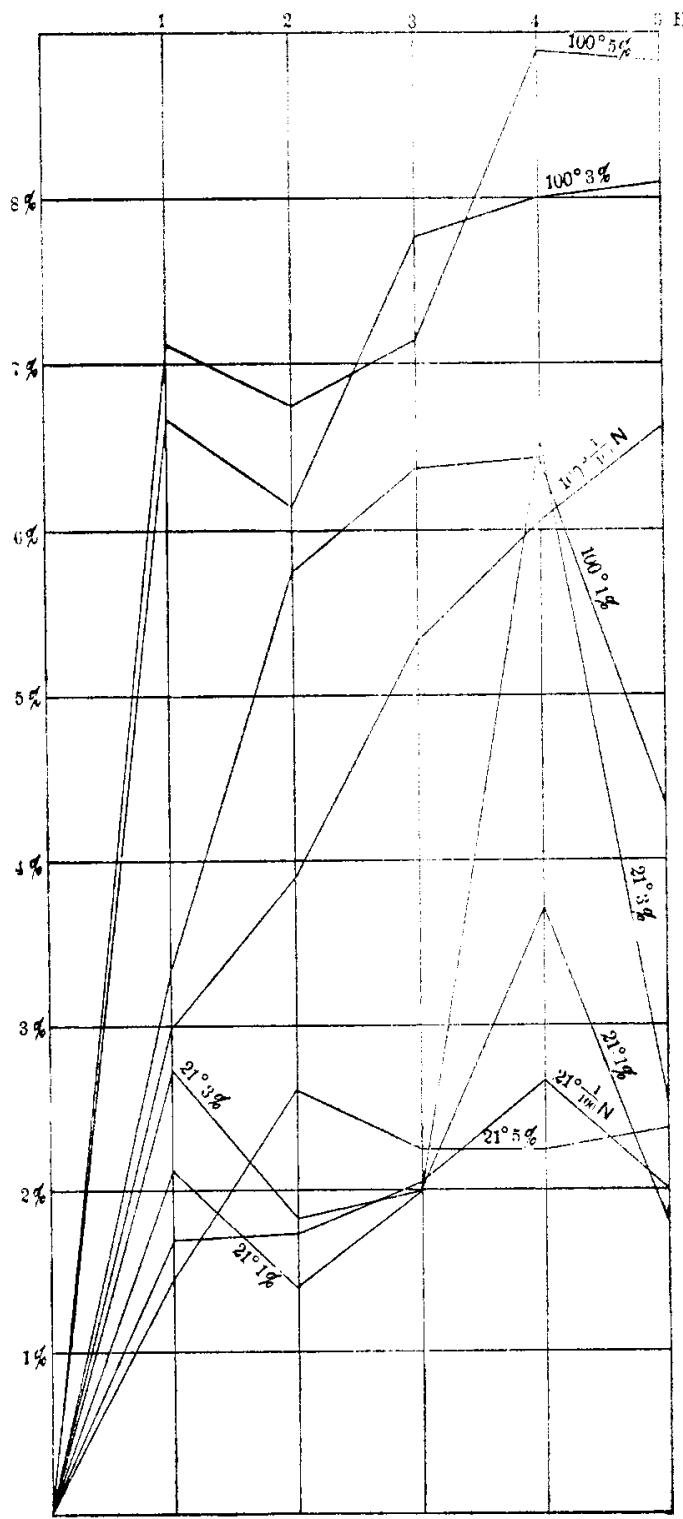

Plate 2. 
A smaller value is here given to the vertical component than in the last case in order that the pyrite and marcasite curves may be platted in full, as they rise so much higher than the arsenopyrite curves. It would be natural to suppose that the curves of arsenopyrite would be more comparable to those of marcasite than to those of pyrite on account of the isomorphism shown by their crystals, and an inspection of the platted curves will show that this is in general, correct. Take for instance the curves showing the action of $\frac{1}{10}$ normal solution of permanganate at ordinary temperature (marked $A, 22^{\circ}, \frac{1}{10} \sigma \mathrm{N}$, etc.); it is seen that at two, three, and five hours the per cent. of oxidation of the contained sulphur in marcasite is almost exactly double that for arsenopyrite. The same condition of affairs is seen on comparing the $\frac{1}{100}$ normal solutions at $100^{\circ}$. It has already been noted that with the more concentrated solutions of permanganate at $100^{\circ}$ the greater part of the oxidation of the arsenopyrite has taken place at the end of the first hour, but in the case of the pyrite and marcasite this is not the case. Their curres of oxidation rise rapidly for the three per cent. and five per cent. solutions, and are hence not comparable to those of arsenopyrite. The entire results given in table (3) are not platted here as they would simply confuse those already shown, but those obtained in the cold would serve to further illustrate the comparison that has been made between arsenopyrite and marcasite. The fact above illustrated that the sulphur in marcasite oxidizes twice as rapidly as that in arsenopyrite is what we might expect from the formula of the two minerals, marcasite being $\mathrm{FeS}_{2}$ and arsenopyrite FeSAs.

Action of Hydrochloric Acid Gas on Arsenopyrite at Elevated Temperatures.-Experiments on the removal of sulphur from arsenopyrite by the action of hydrochloric acid gas at elevated temperatures were tried in the following manner. Two-tenths of a gram of the finely ground mineral, weighed out in a porcelain boat were subjected to the action of a stream of dry hydrochloric acid gas for one, two, and three hours at $300^{\circ}$ and $325^{\circ}$, the temperatures being graded by the melting points of various salts. The sulphur in the material remaining in the boat after the action of the hydrochloric acid was determined as barium 
sulphate, and the amount lost estimated by difference. While no very large amounts of sulphur were removed in this way (except in one case) the amount of arsenic driven off in the process seemed to be considerable, a large sublimate of metallic arsenic forming in the tube, and some passing out with the stream of gas. As will be seen from the results as given in the table (4) the difference in temperature between $300^{\circ}$ and $325^{\circ}$ caused a marked difference in the amount of sulphur removed. The temperature called $300^{\circ}$ was between the melting points of acid sodium sulphate, $\mathrm{NaHSO}_{4}$, and sodium nitrate $\mathrm{NaNO}_{3}$; thit called $325^{\circ}$ was between sodium nitrate, $\mathrm{NaNO}_{3}$, and potassium chlorate, $\mathrm{KClO}_{3}$. The boats containing the mineral were heated in glass tubes so that the reaction could be watched. The amounts of sulphur remored at the lower temperature show no notable increase between the second and third hour, while those at the higher temperature show rapid increase of sulphur lost with the increase of time, perhaps indicating a critical temperature for the reaction of hydrochloric acid with the mineral. A comparison of these results with those obtained by Brown' for pyrite and marcasite is given in the table, the results being calculated to percentage of contained sulphur.

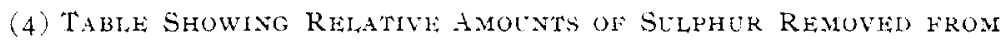
Arsenopyrite, Pyrite anis Marcasite by Action of Dry

Hydrochioric ACID Gas at Flfivaten ThMperatures.

one hour.

Mineral.

Arsenopyrite, $300 \% \ldots$ I. I

Marcasite, $300 \%$......... 7.19

Arsenopyrite, $325 \ldots \ldots \quad 1.62$

Pyrite, $325^{\circ} \ldots \ldots \ldots \ldots \ldots$

Marcasite, $325^{\circ} \ldots \ldots \ldots \ldots$
Two hours.

Three hours.

Amomit Percent. Amount Percent- Amount Percent-

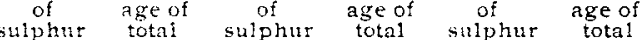
removed. sulphur removed. sulphur. removed. suiphur

\section{Action of a Solution of Copper Sulphate Under Pressure on} Arsenopyrite.-A single experiment on the action of copper sulphate in water solution on this mineral was tried by heating twotenths of a gram of the finely ground mineral with a dilute solution of the salt in a sealed glass tube for six hours at a temperature approximating $200^{\circ}$. But little ferrous iron was found in

1 op. cit. 
the solution, which seems to indicate that the iron present in the mineral is ferric. Some crystalline green arsenate (?) of copper was observed in the tube.

The results of the oxidation experiments detailed in this paper seem to bear out the relationship between arsenopyrite and marcasite indicated in the isomorphism of the two minerals, but the arsenic seems to be a disturbing element which fixes a limit, at an early stage of the oxidation, to further action of any given strength of the oxidant. The experiments with hydrochloric acid gas seem again to show the disturbing action of the arsenic present, which, at the higher temperature at least, is probably removed by heat alone, as is the case with the majority of diarsenides, leaving finally a compound readily acted on by the hydrochloric acid as shown by the large amount of sulphur removed in the three-hour's experiment at $325^{\circ}$. The results of this series of experiments are, therefore, not very significant as compared with those for pyrite and marcasite as given in Brown's paper. If, as indicated by the oxidation experiments, the arsenopyrite is rather to be compared with marcasite, in which Brown has shown that the iron is in the ferrous condition, we may look on arsenopyrite as a ferrous compound, but this conclusion seems to be negatived by the result of the single experiment of decomposing the mineral in a solution of copper sulphate under pressure. In this experiment it will be remembered, no considerable amount of ferrous iron was found. Further research in this latter direction must be made before definite statements as to the constitution of arsenopyrite can be formulated.

University of Pennsyluania, June, I894.

\section{THE PROTEIDS OF THE KIDNEY BEAN.'}

(Phaseolus Vulgaris.)

By Thomas B. OsBorne.

THE only work on the proteids of the kidney bean having importance at the present time, is that of Rithausen. This investigator in $r 883$, stated ${ }^{2}$ that the extract of the white bean 1 Reprinted from the report for 1893 of the Connecticut Agricultural Experiment Station, New Haven.

2 J.prakt. Chem., I03, 204. 